\title{
Rancang Bangun Aplikasi Monitoring Pengamanan Area Objek Vital Berbasis Android
}

\author{
Ade Oktarino $^{1)}$, Hetty Rohayani ${ }^{2)}$ \\ Universitas Adiwangsa Jambi, Jl. Sersan Muslim RT. 24, Kebon Kopi Thehok Jambi Selatan Jambi, Indonesia \\ email: jambeiy5@gmail.com, hettyrohayani@gmail.com
}

\begin{abstract}
Utilization of Security Monitoring Application The Vital Object of Polda Jambi is useful for monitoring the evaluation of vital objects in the jurisdiction of Polda Jambi in order to detect early incidents in the location in order to improve Kambtibmas (Security of Public Order). This application is based on android that is very easy to use and reporting in terms of security guard in PT PLN Dalkit using visual in form of Photos and Videos that can be directly monitored in realtime. PT.PLN Dalkit Jambi is one of the Power Plant to supply electricity in Jambi Province and is one of the Vital Objects recorded in Polda Jambi, so it needs serious supervision under Security of Vital Object of Polda Jambi. In this research using system modeling method using UML (Unified Modeling Language)

Keywords: Apps, Android
\end{abstract}

Intisari - Pemanfaatan Aplikasi Monitoring Pengamanan Objek Vital Polda Jambi berguna untuk monitoring evaluasi objek vital yang ada di wilayah hukum Polda Jambi guna untuk mendeteksi dini kejadian yang ada dilokasi guna meningkatkan Kambtibmas (Keamanan Ketertiban Masyarakat). Aplikasi ini berbasis android yang sangat mudah untuk digunakan dan pelaporan dari segi satpam yang ada di PT PLN Dalkit menggunakan visual berbentuk Foto dan Video yang langsung dapat di monitoring secara realtime. PT.PLN Dalkit Jambi adalah salah satu Pembangkit Listrik yang untuk menyuplai listrik di Provinsi Jambi dan merupakan salah satu Objek Vital yang terdata di Polda Jambi, untuk itu butuh pengawasan cukup serius yang dibawah Pengamanan objek Vital Polda Jambi. Dalam penelitian ini menggunakan metode pemodelan sistem menggunakan UML (Unified Modeling Language)

Kata Kunci : Aplikasi, Android

\section{PENDAHULUAN}

Perancangan sistem adalah Detail bagaimana sistem akan memenuhi kebutuhan informasi sebagaimana ditentukan oleh analisis sistem (Keneth C . Laudon and Jane P . Laudon ( Book Review ), 2007). Survei awal yang penulis lakukan pada PT. PLN Dalkit Jambi, merupakan anak perusahaan yang bergerak di Pembangkit Listrik Jambi, di sector ini sangat dibutuhkan sistem pengamanan objek vital yang langsung termonitor oleh Satuan Pengamanan Objek Vital Polda Jambi (PAM OBVIT) dimana pada sistem kerjanya yang ada di PT. PLN Dalkit Jambi dilakukan oleh anggota keamanan yaitu Satpam. Satpam yang bertugas melakukan patroli dengan cara Pemeriksa Jawaban Tulisan Tangan untuk Ujian Pilihan Ganda mengintari area-area tertentu untuk mengantisipasi jika terjadinya situasi yang tidak diharapkan, jika terjadi kondisi tidak aman Satpam akan memfoto area dan menginformasikan kepada atasan dalam bentuk laporan.

Tentunya cara ini dianggap kurang efektif dan efisien karena mengharuskan Satpam untuk melaporkan kejadian secara lisan dan mengingat ingat dengan jelas situasi yang terjadi serta meyakinkan atasan. Hal tersebut dinilai membuang buang waktu karena kelamaan dalam menjelaskan situasi, sementara dalam situasi genting seharusnya bantuan lansung datang dan informasi yang disampaikan dapat lansung diterima atasan tanpa mengharuskan Satpam untuk menjelaskan keseluruhan.

Aplikasi Android (Company, 2010) menurut (Safaat, 2014) android adaah sebuah kumpulan perangkat lunak untuk perangkat mobile yang mencakup sistem operasi, middleware dan aplikasi utama mobile.

Maka dari itu dibutuhkan Aplikasi berbasis android monitoring pengamanan area objek vital yang merupakan suatu wadah pelaporan objek vital secara realtime yang terintegrasi dalam satu sistem Teknologi Informasi dibawah naungan PAM OBVIT POLDA JAMBI dengan pengedepankan pencegahan, kecepatan tindakan petugas dan kemudahan dalam pengamanan lokasi Objek vital di lingkungan PLN DALKIT Provinsi Jambi.

\section{Tinjauan Pustaka}

Untuk menghasilkan penelitian yang baik dan sesuai dengan sasaran penelitian, maka dibuat sebuah alur penelitian yang yang sesuai dengan judul penelitian dan berisi langkah-langkah yang dilakukan dalam penelitian. Berikut ini merupakan langkah penelitian yang penulis gambarkan melalui alur penelitian, yaitu : 


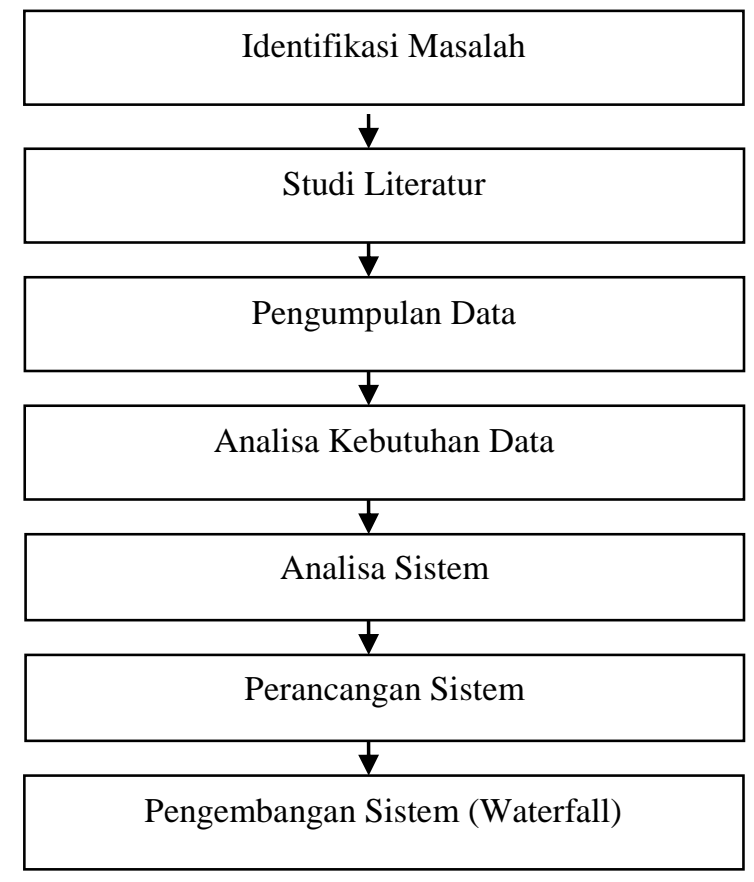

Gambar 1 Kerangka Kerja Penelitian

1. Identifikasi Masalah

Dalam tahap ini, peneliti mengidentifikasi permasalahan yang ada yaitu merumuskan masalah yang akan di teliti. Dengan adanya perumusan masalah, maka penelitian akan menjadi jelas dan terarah.

\section{Studi Literatur}

Hal yang pertama kali dilakukan dalam pembuatan penelitian iniadalah melakukan kegiatan studi literatur. Kegiatan ini dilakukan dengan maksud mempelajari dan memahami teori-teori yang menjadi pedoman dan referensi guna penyelesaian masalah yang di bahas dalam tesis ini dan mempelajari penelitian yang relevan dengan masalah yang diteliti.

\section{Pengumpulan Data}

Sebagai bahan pendukung yang sangat berguna bagi penulis untuk mencari atau mengumpulkan data yang diperlukan dalam penelitian ini, penulis menggunakan 2 (dua) cara, yaitu :

\section{a. Pengamatan (observation)}

Penelitian dengan metode observasi ini dilakukan dengan melakukan pengamatan langsung terhadap objek yang akan diteliti yang bertujuan untuk mengetahui secara langsung mengenai Monitoring Pengamanan Pengamanan Area Objek Vital diwalayah Hukum Polda Jambi berbasis Android.

b. Wawancara (Interview)
Penulis melakukan penelitian lapangan dengan cara melakukan wawancara kepada pihak yang berkaitan untuk memperoleh data-data yang dibutuhkan oleh penulis. Hal ini dilakukan agar penulis mengetahui kegiatan apa saja yang dilakukan . Untuk memperoleh data yang akurat serta relevan agar dapat menghasilkan suatu rancangan aplikasi yang sesuai dengan kebutuhan. Wawancara yang dilakukan dengan dua bentuk, yaitu wawancara terstruktur (dilakukan melalui pertanyaan-pertanyaan yang telah disiapkan sesuai dengan permasalahan yang akan diteliti). Sedangkan wawancara tidak terstruktur (wawancara dilakukan apabila adanya jawaban berkembang di luar sistem permasalahan).

4. Analisa Kebutuhan Data

Tahap selanjutnya adalah tahap analisis kebutuhan data. Pada tahap ini dilakukan analisa atas data-data yang didapat untuk memperoleh data yang benar-benar dibutuhkan dalam penelitian. Hal ini dilakukan dengan tujuan mengelompokan data-data tersebut untuk memperoleh kesimpulan yang valid dan relevan.

\section{Analisa Sistem}

Pada langkah ini dilakukan analisa terhadap sistem monitoring pengamanan yang sedang berjalan di PT PLN Dalkit Jambi saat ini untuk mengetahui masalah yang ada pada Sistem pengamanan yang termonitor dan terintegrasi dengan PAM OBVIT Polda Jambi, sehingga diketahui apa saja kelemahan dan kekurangan yang terdapat pada Aplikasi Monitoring Pengamanan Area Objek Vital Diwilayah Hukum Polda Jambi Berbasis Android.

Selain itu juga dilakukan analisa terhadap interaksi-interaksi yang terjadi di dalam Aplikasi Monitoring Pengamanan Area Objek Vital Diwilayah Hukum Polda Jambi Berbasis Android tersebut yang nantinya akan digambarkan dalam model UML, yaitu : diagram Use Case, Diagram Class, dan Diagram Activity.

\section{Perancangan Sistem}

Pada tahap ini dibuat perancangan struktur data pada sistem dan juga perancangan sistem berupa user interface dengan menggunakan aplikasi Android Studio dan PHPMySQL, sehingga tercipta sebuah layout 
Rancangan Sistem adapun perancangan ini meliputi sebagai berikut :

a. Pemodelan Sistem

Pemodelan Sistem dalam Perancangan Aplikasi monitoring pengamanan area objek vital diwilayah hukum polda jambi berbasis android dengan menggunakan metode pemodelan Unified Modeling Language (UML). Unified Modelling Language atau biasa disingkat UML merupakan bahasa visual untuk pemodelan dan komunikasi mengenai sebuah sistem dengan menggunakan diagram dan teks- teks pendukung. UML hanya berfungsi untuk melakukan pemodelan. Jadi penggunaan UML tidak terbatas pada metodologi tertentu, meskipun pada kenyataannya UML paling banyak digunakan pada metodologi berorientasi objek (Rosa A.S, 2011). Pemodelan ini diantaranya menggunakan Use Case Diagram serta deksripsi diagram sebelum melakukan perancangan user interface.

b. Perancangan Database

Pada perancangan Database bertujuan untuk memenuhi informasi yang berisikan kebutuhankebutuhan secara khusus dan aplikasi-aplikasinya serta memudahkan dalam menerjemahkan struktur informasi guna mendukung kebutuhan-kebutuhan pemrosesan dan beberapa obyek penampilan

c. Perancangan User Interface

Pada perancangan ini merupakan mekanisme komunikasi antara pengguna (user) dengan sistem. Antarmuka pemakai (User Interface) dapat menerima informasi dari pengguna (user) dan memberikan informasi kepada pengguna (user) untuk membantu mengarahkan alur penelusuran masalah sampai ditemukan suatu solusi.

\section{Pengembangan Sistem (Waterfall)}

Pada tahapan pengembangan sistem, penulis menggunakan metode pengembangan sistem yaitu dengan metode waterfall. Menurut (Pressman, 2009) waterfall adalah model klasik yang bersifat sistematis, berurutan dalam membangun software. Fase-fase dalam model waterfall menurut referensi Pressman

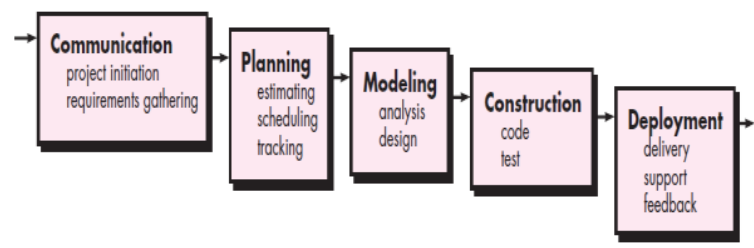

Gambar 2 Model Pengembangan Sistem (Pressman, 2009)

Langkah ini merupakan analisis terhadap kebutuhan software dan tahap untuk mengadakan pengumpulan data dengan melakukan pertemuan dengan customer, maupun mengumpulkan data-data tambahan baik yang ada dijurnal, artikel maupun internet.

1) Planning

Proses planning merupakan lanjutan dari proses communication (analysis requirement). Tahapan ini bisa Gambar diatas merupakan tahap-tahap pada model waterfall. Model air terjun ini merupakan paradigma tertua untuk rekayasa perangkat lunak. Permasalahan yang sering dijumpai saat model air terjun diterapkan adalah sebagai berikut :

a. Proyek perangkat lunak yang nyata jarang mengikuti aliran sekuensial seperti yang dilakuka pada tahap air terjun.

b. Seringkali sulit bagi para pelanggan untuk menetapkan semua spesifikasi kebutuhan secara eksplisit

c. Pelanggan harus memiliki kesabaran karena pelanggan baru bisa melihat hasilnya setelah semua tahap terselesaikan dengan baik. 


\section{METODOLOGI PENELITIAN}

A. Use Case Diagram Untuk APlikasi User

1. Use Case Diagram

Use Case Diagram menggambarkan kegiatan-

kegiatan yang akan diproses oleh sistem serta menjelaskan fitur yang dapat diakses oleh PT. PLN

Dalkit Jambi:

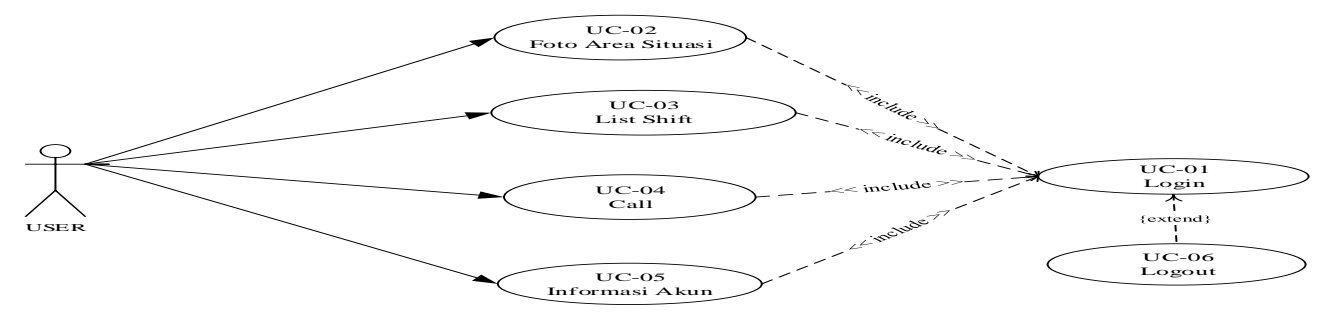

Gambar 3 Use Case Diagram

\section{Deskripsi Use Case Diagram}

Didalam Use case terdapat text untuk menjelaskan urutan kegiatan yang disebut deskripsi use case, adapun deskripsi use case sebagai berikut.
1) Deskripsi use case login

Berikut ini adalah interaksi antar pengguna sistem (aktor) pada use case dengan skenario yang telah di tentukan. Adapun skenario berikut adalah interaksi aktor untuk menampilkan login yang akan dijelaskan pada tabel berikut :

Tabel 1 Deskripsi use case login

\begin{tabular}{|c|c|c|}
\hline Nama & \multicolumn{2}{|l|}{ Login } \\
\hline ID Use Case & \multicolumn{2}{|l|}{ UC-01 } \\
\hline Aktor & \multicolumn{2}{|l|}{ User } \\
\hline Deskripsi & \multicolumn{2}{|c|}{ User melakukan login untuk otentikasi dalam pengecekan dan modifikasi data } \\
\hline Exception & \multicolumn{2}{|c|}{ Proses login gagal } \\
\hline Pre Condition & \multicolumn{2}{|c|}{ Nama dan Kata Sandi telah tersimpan dalam database } \\
\hline \multicolumn{2}{|c|}{ Aktor } & Sistem \\
\hline \multicolumn{3}{|c|}{ Skenario normal } \\
\hline \multicolumn{3}{|c|}{$\begin{array}{l}\text { 1. User melakukan login dengan mengetik } \\
\text { Nama dan Kata Sandi }\end{array}$} \\
\hline \multicolumn{3}{|c|}{ 2. User memilih dan mengklik Login } \\
\hline & & $\begin{array}{l}\text { 3. Melakukan authentication/validasi Nama dan Kata } \\
\text { Sandi untuk masuk ke sistem dan data lengkap }\end{array}$ \\
\hline & & 4. $\quad$ Validasi berhasil, User memasuki menu utama \\
\hline \multicolumn{3}{|c|}{ Skenario alternative } \\
\hline $2 . \mathrm{a}$ & & User memilih dan mengklik Cancel \\
\hline 2.b & & Keluar dari sistem \\
\hline 3.a & & Validasi data dan data tidak lengkap \\
\hline 3.b & & $\begin{array}{l}\text { Sistem menampilkan pesan peringatan dan memberikan } \\
\text { kesempatan User untuk kembali }\end{array}$ \\
\hline Post condition & User sudah masuk sis & n untuk mengolah data \\
\hline
\end{tabular}

2) Deskripsi Use Case Login

Berikut ini adalah interaksi antar pengguna sistem (aktor) pada use case dengan skenario yang telah di tentukan. Adapun skenario berikut adalah interaksi aktor untuk menampilkan data Foto Situasi Area yang akan dijelaskan pada tabel berikut: 
Tabel 2 Deskripsi Use Case Foto Situasi Area

\begin{tabular}{|c|c|c|}
\hline Nama & \multicolumn{2}{|l|}{ Foto Situasi Area } \\
\hline Id use case & \multicolumn{2}{|l|}{ UC-02 } \\
\hline Aktor & \multicolumn{2}{|l|}{ User } \\
\hline Deskripsi & \multicolumn{2}{|c|}{ Aktor dapat memfoto Situasi Area } \\
\hline Exception & \multicolumn{2}{|c|}{ HP Tidak dilengkapi fitur kamera } \\
\hline Pre condition & \multicolumn{2}{|c|}{ Aktor telah dalam keadaan login } \\
\hline \multicolumn{2}{|l|}{ Aktor } & Sistem \\
\hline \multicolumn{3}{|c|}{ Skenario normal } \\
\hline \multicolumn{3}{|c|}{ 1. User memilih menu Foto Situasi Area } \\
\hline \multirow{2}{*}{\multicolumn{3}{|c|}{ 3. Klik tombol fotret }} \\
\hline & & \\
\hline \multicolumn{3}{|r|}{ 4. Menangkap dan menyimpan Gambar } \\
\hline \multicolumn{3}{|c|}{ 5. Input informasi situasi klik kirim } \\
\hline & & 6. Kirim informasi situasi kepada Atasan \\
\hline \multicolumn{3}{|c|}{ Skenario alternative } \\
\hline- & & - \\
\hline Post condition & \multicolumn{2}{|c|}{ User berhasil Memfoto Situasi Area } \\
\hline
\end{tabular}

\section{3) Deskripsi Use Case List Shift}

Berikut ini adalah interaksi antar pengguna sistem (aktor) pada use case dengan skenario yang telah di tentukan.
Adapun skenario berikut adalah interaksi aktor untuk menampilkan data List Shift yang akan dijelaskan pada tabel berikut

Tabel 3 Deskripsi Use Case List Shift

\begin{tabular}{|l|l|}
\hline Nama & List Shift \\
\hline Id use case & UC-03 \\
\hline Aktor & User \\
\hline Deskripsi & Aktor melihat List Shift \\
\hline Exception & Data tidak tersedia \\
\hline Pre condition & Aktor telah dalam keadaan login \\
\hline Aktor & Sistem \\
\hline Skenario normal & \\
\hline 1. User memilih menu List Shift & 2. Sistem menampilkan list Shift \\
\hline \multicolumn{2}{|l|}{} \\
\hline $3 . \quad$ Klik tombol salah satu List & 4 Tampilkan Informasi Detail Shift \\
\hline \multicolumn{2}{|l|}{} \\
\hline Skenario alternative \\
\hline-
\end{tabular}

4) Deskripsi Use Case Call

Berikut ini adalah interaksi antar pengguna sistem (aktor) pada use case dengan skenario yang telah di tentukan.
Adapun skenario berikut adalah interaksi aktor untuk menampilkan data Call yang akan dijelaskan pada tabel berikut:

Tabel 4 Deskripsi Use Case Call

\begin{tabular}{|l|l|}
\hline Nama & Call \\
\hline Id use case & UC-04 \\
\hline Aktor & User \\
\hline Deskripsi & Aktor melihat Call \\
\hline Exception & - \\
\hline Pre condition & Aktor telah dalam keadaan login \\
\hline Aktor & Sistem \\
\hline Skenario normal \\
\hline
\end{tabular}




\begin{tabular}{|c|c|c|}
\hline \multicolumn{3}{|c|}{ 1. User memilih menu Call } \\
\hline & & 2. Sistem menampilkan Call Center dan WhatsApp \\
\hline \multicolumn{3}{|c|}{ 3. $\quad$ Klik tombol salah satu fungsi Call } \\
\hline & & 4. Sistem menghubungi pimpinan \\
\hline \multicolumn{3}{|c|}{ Skenario alternative } \\
\hline- & & - \\
\hline Post condition & User berhasilCall & \\
\hline
\end{tabular}

5) Deskripsi Use Case Informasi Akun tentukan. Adapun skenario berikut adalah interaksi

Berikut ini adalah interaksi antar pengguna sistem aktor untuk menampilkan data Call yang akan (aktor) pada use case dengan skenario yang telah di dijelaskan pada tabel berikut:

Tabel 5 Deskripsi Use Case Informasi Akun

\begin{tabular}{|l|l|}
\hline Nama & Informasi Akun \\
\hline Id use case & UC-05 \\
\hline Aktor & User \\
\hline Deskripsi & Aktor melihat Informasi Akun \\
\hline Exception & - \\
\hline Pre condition & Aktor telah dalam keadaan login \\
\hline Aktor & Sistem \\
\hline Skenario normal \\
\hline User memilih menu Informasi Akun & \\
\hline \multicolumn{2}{|l|}{} \\
\hline Skenario alternative & 2. Sistem menampilkan Detail Informasi Akun \\
\hline- & - \\
\hline Post condition & User berhasillnformasi Akun \\
\hline
\end{tabular}

6) Deskripsi Use case Logout

Berikut ini adalah interaksi antar pengguna sistem (aktor) pada use case dengan skenario yang telah di tentukan. Adapun skenario berikut adalah interaksi aktor untuk menampilkan data Informasi Akun yang akan dijelaskan pada tabel berikut:

Tabel 6 Deskripsi Use case Logout

\begin{tabular}{|l|l|}
\hline Nama & Logout \\
\hline Id use case & UC-6 \\
\hline Aktor & User \\
\hline Deskripsi & Aktor tidak melakukan pengolahan data dan keluar dari sistem \\
\hline Exception & Koneksi gagal ditutup \\
\hline Precondition Aktor sudah login \\
\hline \multicolumn{2}{|c|}{ Aktor } \\
\hline Skenario normal & Sistem \\
\hline 1. Aktor melakukan logout & 2. Menutup koneksi ke database aktor \\
\hline \multicolumn{2}{|c|}{} \\
\hline \multicolumn{2}{|c|}{ 3. Koneksi berhasil ditutup. } \\
\hline Post condition & Aktor keluar dari sistem \\
\hline
\end{tabular}

\section{Tampilan Aplikasi User PT.PLN Dalkit}

Desain program merupakan langkah awal untuk menganalisis situasi, merencanakan strategi dan struktur, serta menghasilkan persiapan rencana kerja yang matang.
1. Tampilan Halaman Login

Berikut ini adalah tampilan halaman login pada aplikasi yang di gunakan User PT. PLN Dalkit Jambi 


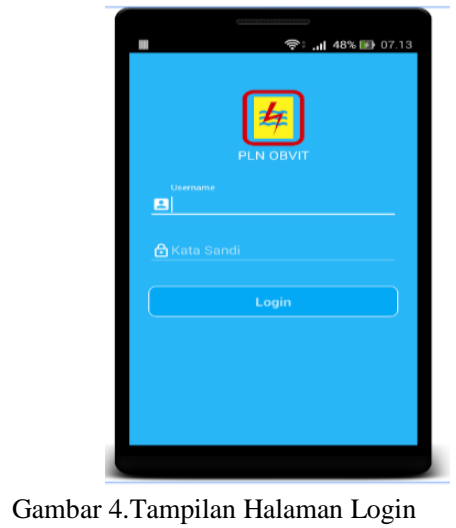

2. Tampilan Halaman Foto Area Situasi

Berikut ini adalah tampilan Halaman Foto Area Situasi pada aplikasi yang di gunakan User PT. PLN Dalkit Jambi

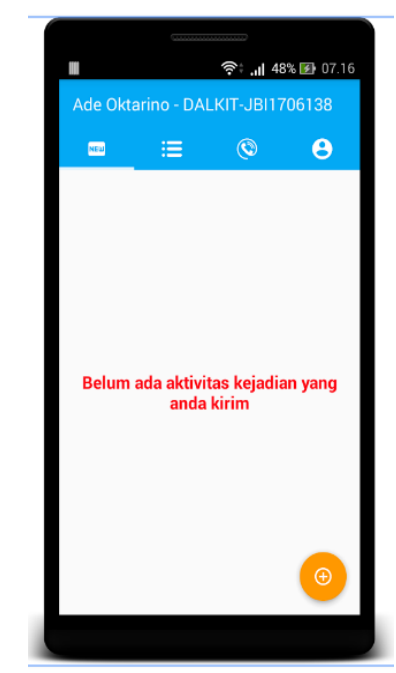

Gambar 5. Tampilan Foto Area Situasi

3. Tampilan Halaman Kode Shift

Berikut ini adalah tampilan halaman Kode shift pada aplikasi yang di gunakan User PT. PLN Dalkit Jambi

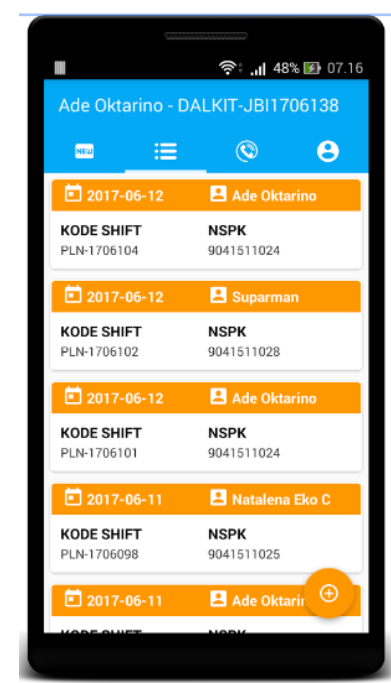

Gambar 6. Tampilan Use case Kode Shift

\section{Tampilan Halaman Call}

Berikut ini adalah tampilan Halaman Call telpon penting ke PAM OBVIT Polda Jambi untuk situasi Darurat pada pada aplikasi yang di gunakan User PT. PLN Dalkit Jambi

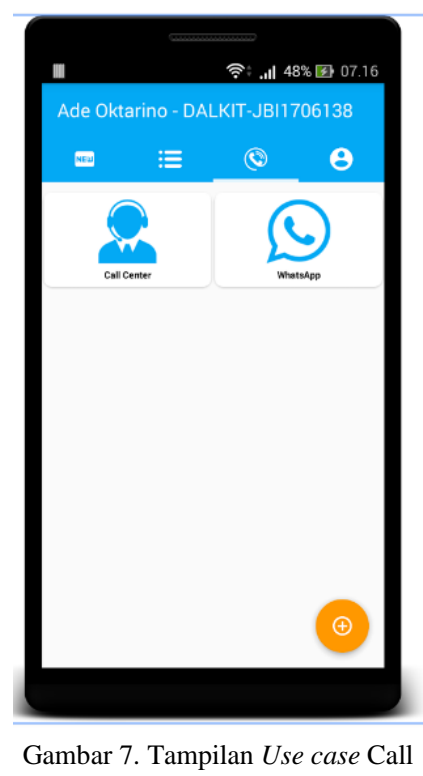

5. Tampilan Halaman Informasi Akun

Berikut ini adalah tampilan halaman informasi akun pada pada aplikasi yang di gunakan User PT. PLN Dalkit Jambi 


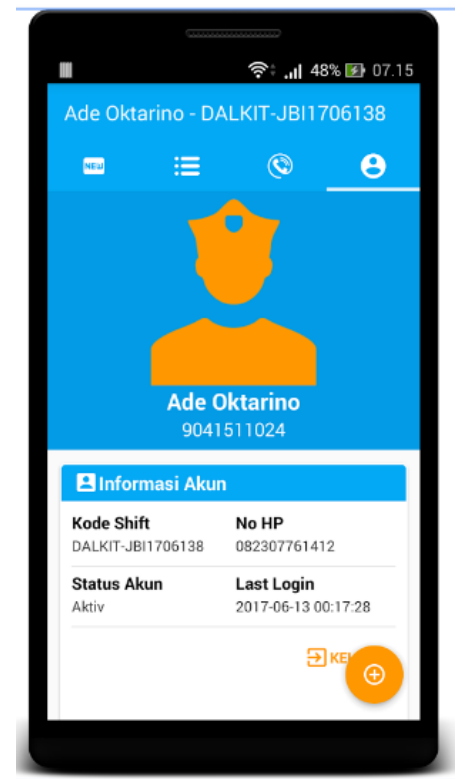

Gambar 8. Tampilan Use case Informasi Akun

6. Tampilan Halaman Laporan Terkirim

Berikut ini adalah Tampilan Halaman Laporan

Terkirim pada pada aplikasi yang di gunakan User

PT. PLN Dalkit Jambi

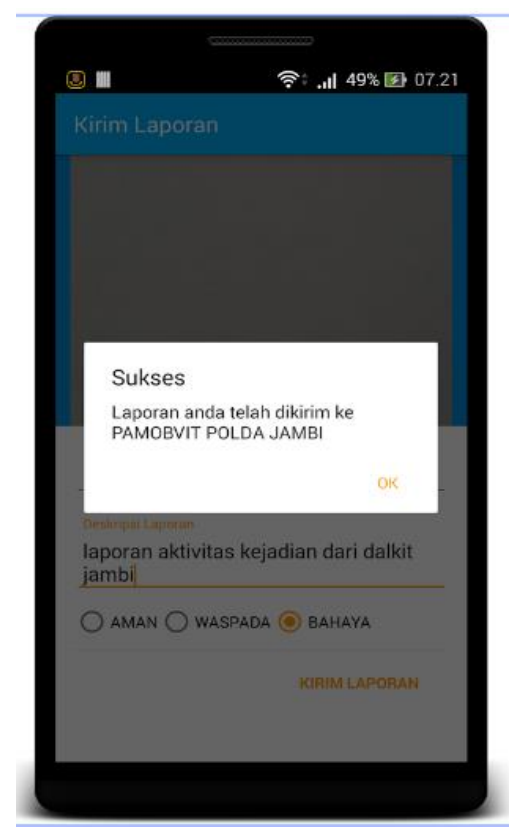

Gambar 9. Tampilan Use case Laporan Terkirim

\section{KESIMPULAN DAN SARAN}

Dari semua pembahasan yang dilakukan sebelumnya, maka penulis menarik kesimpulan tentang
Aplikasi Dalkit Jambi sebagai sarana informasi adalah sebagai berikut:

1. Penelitian ini menghasilkan

Aplikasi Monitoring Pengamanan Area Objek Vital Diwilayah Hukum Polda Jambi Berbasis Android (Studi Kasus : Pt Pln Dalkit JAMBI) Terdapat fitur Foto area situasi, kode shift, call dan Informasi Akun.

2. Apikasi ini dapat membantu bagian Keamanan dalam penyampaian informasi dan memperoleh informasi Keamanan dalam bentuk laporan kepada pimpinan

3. Aplikasi ini dapat membantu dalam menyampaikan informasi Keamanan dengan lebih efektif karena sistem dilengkapi fungsi foto dan lansung telepon sehingga informasi yang dibutuhkan lebih cepat disampaikan.

\section{Daftar PUStaka}

[1] Company, G. (2010). Android Studioverview | Android Developers.

[2] Keneth C . Laudon and Jane P . Laudon ( Book Review ). (2007). MANAGEMENT INFORMATION SYSTEMS: Managing the Digital Firm - 9th edition, authors: Keneth C Laudon and Jane P . Laudon ( Book Review ). International Journal, II(1), 103-105.

[3] Pressman, R. S. (2009). Software Engineering A Practitioner's Approach 7th Ed-Roger S. Pressman. Software Engineering A Practitioner's Approach 7th Ed - Roger S. Pressman. https://doi.org/10.1017/CBO9781107415324.004

[4] Rosa A.S, and M. S. (2011). Modul Pembelajaran Rekayasa Perangkat Lunak (Terstruktur dan Berorientasi Obyek). Bandung: Modula (Vol. https://doi.org/10.1017/CBO9781107415324.004

[5] Safaat, H. N. (2014). Pemrograman Aplikasi Mobile Smartphone dan Tablet PC Berbasis Android. Informatika. https://doi.org/10.1007/s13398-014-0173-7.2 